\title{
Dogs Therapy for Children with Motor Disabilities
}

\author{
DOI: 10.26466/opus.937387
}

\author{
Olivera Rashikj Canevska * - Nergis Ramo Akgün ** \\ * Prof. Dr, Ss. Cyril and Methodius University, Faculty of Philosophy, Skopje/North Macedonia \\ E-Mail: oliverarasic@fzf.ukim.edu.mk \\ ORCID: 0000-0003-2385-5450 \\ ** Assist. Prof. Dr, Canakkale Onsekiz Mart University,Faculty of Education,Canakkale/Turkey \\ E-Mail: nergisramoakgun@comu.edu.tr \\ ORCID: 0000-0002-0982-5733
}

\begin{abstract}
Dog therapy is the application of specially trained dogs to achieve general well-being or treatment in different categories of disabilities. Like other animals used for therapeutic purposes, dogs accept, offer comfort, do not condemn and are a great companion during treatment and therapy. Dog therapy builds on the prior existing connection between humans and animals. Engaging with a friendly dog can enable improvements in many physical and mental difficulties. It can help decrease blood pressure and improve the cardiovascular health in general. It can release endorphins, too which ensue a calming effect. This can help ease pain, decrease stress, and enhance child's psychological state in general. Dog therapy can be used in various ways. Determined objectives are significant part of the therapy, and the progress should be registered with follow up during the structured sessions. The aims of the dog therapy programs involve: enriching motor skills and synchronized movement, reinforcing assisted or autonomous movement, increasing self-esteem, enriching verbal communication, improving the social skills development, increasing the desire to join in activities, enriching interactions with others, stimulating the determination to exercise. This research is a qualitative study that aimed to investigate the effect of dog therapy on students with motor disabilities. The realization of the research took place within three months. The research was conducted in children with motor disabilities, between the ages of 7 and 8 by a special educator and experienced trainer at the Special Center for dog therapy in Skopje, Republic of North Macedonia. The research was organized as a case study format. Researches indicate that the presence of a dog during the therapies leads to improvement in children mood, enrichment in their will to actively participate during the treatments, expression of emotions easily, improvement in communication and psychomotor development and achievement of a range of physiological benefits.
\end{abstract}

Keywords: therapy, assistance dogs, disability, motor development. 


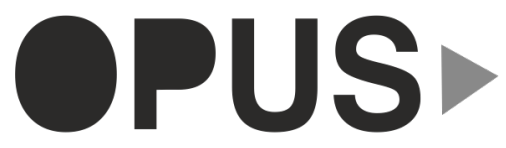

Uluslararası Toplum Araştırmaları Dergisi International Journal of Society Researches
E-ISSN : 2528-9535

Yıl Year:11

Cilt Volume: 18

Sayı Issue :41

Eylül September 2021

Makalenin Geliş Tarihi Received Date: 15/05/2021

Makalenin Kabul Tarihi Accepted Date: 02/07/2021

\section{Ortopedik Yetersizliği Olan Çocuklar için Köpek ile Terapisi}

\section{Öz}

Köpek terapisi, farklı yetersizlik kategorilerinde genel durumun iyiliğini veya tedavisini sağlamak için özel olarak eğitilmiş köpekler ile uygulanmasıdır. Tedavi amaçlı kullanılan diğer hayvanlar gibi köpekler de tedavi ve terapi strasinda uygulamayı kabul eder, rahatlık sunar, kınamaz ve harika bir arkadaştır. Köpek terapisi, insanlar ve hayvanlar arasinda önceden var olan bağa dayanır. Arkadaş canlısı bir köpekle ilişki kurmak, birçok fiziksel ve zihinsel zorlukta iyileşme sağlayabilir. Kan basıncın düşürmeye ve genel olarak kardiyovasküler sağhlğgı iyileştirmeye yardımo olabilir. Sakinleştirici bir etki yaratan endorfinleri de serbest bırakabilir. Bu, ağrıyı hafifletmeye, stresi azaltmaya ve genel olarak bir çocuğun psikolojik durumunu iyileştirmeye yardımco olabilir. Köpek terapisi çeşitli şekillerde kullanulabilir. Hedeflerin belirlenmesi terapinin önemli bir parçasıdır ve ilerleme yapılandırılmış seanslar sırasında takip ile kaydedilmelidir. Köpek terapi programlarının amaçları şunlardır: motor becerileri ve senkronize hareketi zenginleştirmek, yardıml veya otonom hareketi güçlendirmek, öz saygıyı artırmak, sözlü iletişimi zenginleştirmek, sosyal beceri gelişimini geliştirmek, faaliyetlere katılma arzusunu artırmak, başkalarıla etkileşimi zenginleştirmek, egzersiz yapma kararlılı̆̆ını teşvik etmek. Bu araştırma, köpek terapisinin ortopedik yetersizliği olan öğrenciler üzerindeki etkisini araştırmayı amaçlayan nitel bir çalışmadır. Araştırma üç ay içinde gerçekleşmiştir. Araştırma, Kuzey Makedonya Üsküp Özel Köpek Terapi Merkezi'nde özel bir eğitimci ve deneyimli ĕğitmen tarafindan 7-8 yaş arası ortopedik yetersizliği olan çocuklarla gerçekleştirildi. Araştırma, vaka analizi formatında düzenlenmiştir. Araştırmalar, terapiler sırasında bir köpeğin varlığının, çocukların ruh hallerinde iyileşmeye, tedavilere aktif olarak katılma iradelerinde zenginleşmeye, duyguların kolayca ifade edilmesine, iletişimde ve psikomotor gelişimde iyileşmeye ve bir dizi fizyolojik faydaya ulaşılmasına yol açtı̆̆ını göstermektedir.

Anahtar Kelimeler: terapi, asistan köpekler, yetersizlik, motor gelişimi. 


\section{Introduction}

Historically, the first data of the animal contribution to the human welfare date back to the 1600 year, when John Lock wrote in his discussions about the use of small animals in order to develop empathy and responsibility in children (Fine, 2000). Animal housing and domestication began more than 2 million years ago, and in the Ancient Greece were noticed emotional and physical benefits of the contact with animals. In 1792 year in England the farm animals were used in the treatment of mentally ill patients, in order to reduce the isolation and restrictions (Baun and McCabe, 2000). Later in Germany, animals have been used in therapeutic goals in the institutions for mentally ill and homeless people, and in 1942 animals have been used for the treatment and healing of the war invalids in America. In 1960, the human animal bond was conceptualized by a psychologist Boris Levinson, and he created the term animal assisted therapy, by using his dog while working with a withdrawn and mentally impaired young boy and noticing significant positive changes (Levinson and Mallon, 1997). The dog is the first animal that human domesticated and kept at home. In a 14.000 years old tomb in Israel, the remains of a man lying with one hand on the chest of a small dog were found, and the domestication also began in Israel 12.000 years ago. The history of human evolution is believed to be directly related to the evolution of dogs, believing that it caused functional changes in the human brain. The use of dogs in the treatment of persons with disabilities has been noted in the middle century in Belgium. Since the 1970s when the dog assisted therapy has been introduced in clinical conditions, such a treatment was offered in therapeutic centers, special needs programs, hospitals, nursing homes for elderly, prisons and institutions for mental health, without any age limits. It is effective for children, adolescents, adults and elderly (Alliance of therapy dogs, 2018).

Our findings overlap the results of the Tepfer's research in 2017, according to which dog therapy plays an important role in the quality of life, improving the motor skills and physical activities. The authors concluded that the family dog could have influence in a healthy lifestyle in children with cerebral palsy. Dilek Elmaci and Sibel Cevizci in 2015 showed that 
dog therapy and activities can be a method of support for routine procedures for the children with cerebral palsy, physical and intellectual disabilities during their process of rehabilitation. Emily Howell-Forbes (2014) in her study of the influence of dogs on the outcome of occupational therapy in children with cerebral palsy noticed significantly more vocalizations in respondents when the dog was present. In line with our findings are the results of LaFrance, Garcia and Labreche in 2007, which show that verbal behaviors of patients can be improved by the presence of a therapeutic dog. Through intensified speech and language therapy in rehabilitation conditions by applying participatory observation, the researchers assumed that the presence of the dog has the ability to induce the socialverbal and social-nonverbal communication.

\section{Dog Therapy}

An animal assisted treatment is each intervention that purposely involves animals as part of a therapeutic process. Such interventions are commonly used in patients with physical problems, intellectual, psychic, neurologic and motor impairments, but can also be used in people with depression, anxiety, posttraumatic stress etc. There is a need for examinations and evaluations before each implementation, in order to determinate the possible contraindications. The implementation of the intervention can require multidisciplinary approach with different tasks and responsibilities, depending of the intervention. The animal assisted interventions are divided in three categories (American Veterinary Medical Association, 2019): Animal assisted therapy - an intervention used as support to other therapies (co-therapy) focuses on the treatment of physical problems, intellectual, psychic, cognitive, emotional, attachment, neurological and motor impairments; Animal assisted education - educational and/or rehabilitation intervention intended for healthy, but also persons with disabilities, and with behavioral disorders. The intervention aims to improve the psychophysical and social wellbeing and the quality of life of the persons, increasing their self-esteem (Rosenthal, 2020).

The animals are used for the behavioral reeducation. Such intervention is commonly used in the prolonged or recurrent hospitalizations in rehabilitation centers, attachment problems in the childhood or adolescence, 
emotional disturbances, behavioral disorders and sociocultural adaptation; Animal assisted activity - episode, recreational intervention intended for healthy persons and persons with disabilities, in order to improve their quality of live (Cockerham, 2016). The animal bond in the activities presents a source of knowledge and sensory-emotional stimulation. In some cases, an animal assisted activity is introductory step in the education or therapy and aim to develop skills through animal care, increasing responsibility, and stimulating motor activity (Kruger, and Serpell, 2010). In general, all three categories of interventions are performed by a multidisciplinary team, where each member is trained for the animal assisted intervention.

The animal used in the intervention is previously detail examined by the veterinary, and his behavior is monitored during the hall intervention. All animals included in the interventions, especially those exposed to direct contact and activities, have to be trained and educated on specific skills, in order to acquire necessary competencies. The most common intervention is canine (dog) assisted intervention, an animal that is most often present in people's lives. In addition, the intervention is not just a walk with the dog or a game, it is a planned program where the individual engages with the animal in a focused, previously specified and detailed program (Kruger and Serpell, 2006). In canine assisted interventions there are three types of interventions: Dogs for therapeutic visits: these are pets that owners occasionally bring to visit patients who have been hospitalized for a long time in hospitals, nursing homes, rehabilitation institutions. Dogs improve psychophysical condition. According to research, contact with dogs causes the production of oxytocin (a hormone of connection), dopamine (a hormone of happiness) and decrease the amount of cortisol (a stress hormone); Dogs used as mediators in the treatment and rehabilitation: help physiotherapists, occupational therapists, special educators and rehabilitators, speech therapists in the realization of the treatment goals. Enable improvement in the gross and fine motoric, visio-motor coordination, balance, speech, interaction. A new type of intervention is the "Reading to Dogs" technique.

The program is designed to help the enlarged number of children with reading and language skills difficulties to build and develop verbal skills 
and vocabulary, improve reading comprehension, and develop self-confidence. Dogs are passive listeners who do not criticize or suggest, have enough time to listen without condemnation and act motivational, stimulating, calming (Pillow-Price et all., 2014). Service dogs: these dogs usually work in nursing homes or hospice and are good trained to help the users in the realization of their daily obligations, without dependence of another person. In the past years there are several different types of service dogs: a dog guide for blind, dog alert for the deaf people, dog wheelchair guide for physically disabled people, diabetic alert dog, an epileptic seizure alert dog, dogs that help in epileptic seizures, psychiatric dogs, dogs for supporting children with autism spectrum disorder, dogs for the detection of allergens (Lundqvist, et al., 2017). No matter what form of intervention is used, dogs used should always be well-trained and prepared for different situations and contacts with people.

Dogs can be of different breeds and of different character, but all must have certain characteristics necessary for the successful implementation of the intervention: to be calm, stable (not explosive), not to be aggressive, to be able to inhibit their impulses, to cope with unpredictable situations (slippery floor, strong odors, loud noises, etc.) tolerant of hugging and strangers, to have a desire to play and cooperate. Before training, dogs are evaluated, in addition to physical examination, age, their character and relationship with the guardian is assessed. Dog training lasts from 6 weeks for therapeutic visits and reading up to 18 months for various services (Clonowski, 2015). It is well known that interacting with a loveable, friendly pet, specifically a dog, has noticeable advantages. Some of the most common benefits are: Physical health - with the releasement of endorphins (oxytocin) which has a calming effect the overall physical pain is reduced, the blood pressure is lower, the cardiovascular health is improved in general, and also the amount of medication some people need is reduced; Mental health - reduces the feelings of deprivation and isolation, reduces depression, lifts the spirit, stimulates communication, provides the feeling of comfort, expands socialization, increases the sense of community, lessens anxiety, reduces boredom, helps children in overcoming some emotional or speech disorders, lessens the feeling of loneliness, motivates the child to recover faster; Literacy support (reading) - there is improvement in literacy skills, the self-confidence is increased and the 
self-awareness in children is reduced, the therapy with dogs is helping them to focus better providing non-stressful environment, the children are also encouraged to love reading and learning in general; Physical therapy - children are motivated to exercise longer and to move more during the realization of activities, it is also noticed that they are stretching farther are heighten the number of joint movements, which ensures and enhances the motor skills, there is also improvement in time needed for recovery in some children (PAWS, 2005). Trained dogs are playing very important role in society, they are making their owners' life easier by helping them function during daily activities. Old, young, children have different benefits from dog therapy.

The presence of a dog helps people to overcome speech disorders, relief from anxiety, help with dementia, stimulate communication, help children with autism spectrum disorders, physiological benefits, promote socializing (Becic, 2019). Therapy Dogs United notes that working with dogs has some benefits such as: giving commands to the dog increases the communication skills and also the problem solving skills, helps on learning how to make friends with others, expressing blocked and difficult thoughts and emotions, brings the power of touch and inclination in setting the therapy, provides a calming presence, helps improve anxiety or depression, increase on the level of interest and focusing, increased motivation and more positive attitude (Staff, 2018). Research also shows that interacting with and caring for a dog reduces stress, anxiety and depression, increases physical activity and improves communication and social skills (Marcoux, 2019).

\section{Motor Disabilities}

Motor disability is the partial or complete impairment in a body part function, usually the limb or limbs. The outcome can be muscle weakness, poor endurance, deficiency of muscle control or total paralysis. Physical disability can affect locomotor, motor or sensory systems and be either medical or psychological in origin (Tingle and Nelsin, 2005). Accurate diagnosis and follow-up on patients depend on the availability of an appropriate reference data (Çolak et al., 2021). The reasons for the physical disability of the population from a special education and rehabilitation point of view 
are divided into: Postnatal - traumatic injuries; Prenatal (genetic); and Diseases - correlated with age. People with motor disabilities are defined in the following groups: Traumatic injuries - injury of the spinal cord, loss or damage to the extremities; Congenital causes - spina bifida, cerebral palsy, muscular dystrophy, congenital anomalies of the extremities, spine, etc. Diseases correlated with age - Parkinson's disease, arthritis, multiple sclerosis (Ajdinski et al., 2007). Disorders of gross and fine motor functionality in children and adolescents can be categorized into 5 different levels according to or using the Gross Motor Function Classification System (GMFCS): level I of GMFCS (able to walk indoors and outdoors and climb stairs without using the arms for support; able to perform normal activities such as jumping and running; has reduced coordination, speed, and balance); GMFCS Level II ( Able to climb stairs with a support, has difficulty with asymmetrical surfaces and in crowded situations; has minimal ability to jump or run); GMFCS Level III (indoor and outdoor walk with surface aids; can climb stairs using a handrail; can lift a hand wheelchair; surfaces); Level IV of the GMFCS (the walking ability is severely limited even with assistive devices; uses a wheelchair most of the time and can move whit it on his or her own; can make transfers with or without using assistance); GMFCS V level (has physical impairments that limit voluntary movement control; inability to maintain head and neck position against gravity; impaired condition in all areas of motor function; unable to sit or stand alone, even with assisted movement equipment; cannot walk on its own, but can use mobile mobility) (Palisano, Rosenbaum, Barlett, and Livingsto, 2007). Spinal cord injuries - Tetraplegia or paraplegia is a loss of use of the arms, legs and torso, usually caused by a spinal cord injury, especially in the area of the fifth to seventh vertebrae. This level of paralysis is also associated with loss of sensation from the neck down. The most common causes of spinal cord injuries are accidents, violence, falls, sports, etc. (Henderson, 2012).

Cerebral palsy. The word "cerebral" means that it has to do with the brain. The word "paralysis" means weakness or problems with body movement. That is, cerebral palsy is a disorder that impairs the child's ability to control their muscles. Abnormal brain development or brain injury can cause cerebral palsy. Impairment affects the part of the brain that controls coordination, body movement, and posture (Arifi and Rashikj- 
Canevska, 2020). Brain damage usually occurs before birth, but can also happen during birth or the first years of life. The exact cause of cerebral palsy is not known. Some of the possible reasons include: asphyxia neonatorum or lack of oxygen to the brain during childbirth; mutations in genes that result in abnormal brain development; severe jaundice in the newborn; maternal infections, such as measles and herpes syndrome; infections of the brain, such as encephalitis and meningitis; intracranial hemorrhage or bleeding in the brain; head injuries as a result of a car accident, fall or child abuse. Cerebral palsy is the most common cause of motor disability in childhood (Sanger, 2015). According to the Centers for Disease Control and Prevention (CDC), at least 1.5 to 4 out of every 1,000 children worldwide have cerebral palsy (Shroff et al., 2014). Cerebral palsy is divided into several main types: Topographic division: monoplegia and monoparesis, diplegia and diparesis, triplegia, quadriplegia and so on; Anatomical-physiological: Pyramidal: spastic; Extrapyramidal: and Ataxic: combined type (Pavone and Testa, 2015). The most common form of cerebral palsy is spastic cerebral palsy, in which the child has increased muscle tone /firmness. The child's back, arms and legs are stiff and contracted, making movement difficult.

When both legs are affected (spastic diplegia), the tight muscles in the hips and legs often cause the legs to turn inward and cross at the knees when walking, which is called the "scissor position". If one side of the body is involved (spastic hemiplegia), the arm is often more severely affected by the leg. If all four limbs and the body are involved (spastic quadriplegia or whole body involved), walking alone difficult or even impossible. Additionally, the muscles of the mouth and tongue can also be affected, making swallowing and eating difficult. Athetoid (dyskinetic); the child with cerebral palsy has low muscle tone / looseness, which makes the limbs weak and loose. Athetoid cerebral palsy causes uncontrolled and involuntary movements of the whole body. It can be difficult for the child to sit up or walk. Ataxic; rare form of cerebral palsy that affects the perception of balance and depth. Has poor coordination, unstable gait, and difficulty with precise movements, such as using a pen or buttoning a shirt. Mixed; In mixed cerebral palsy, there are symptoms of spastic and athetoid cerebral palsy. Some muscles are firm and others are loose. There is numbness and involuntary movements (Krigger, 2006). Children and adults with 
cerebral palsy need long-term care with a specialized medical team. In order to reduce the muscle tone tension and improve the child's functional abilities, the use of medications is needed.

The medications can also be used for treating pain and managing complications linked with spasticity or other cerebral palsy symptoms. There are a lot of different therapies that are essential during the cerebral palsy treatment: Physical therapy: Music training and exercises is beneficial for the child's flexibility, motor development, balance, and agility. In the first years after birth, physical and occupational therapists can implement various treatment to support the head and provide body control, grasping and rolling. Later, both therapists are included in wheelchair use assessments; Occupational therapy: helps the child to gain independence in home routines and daily activities at school and home with the rehabilitation treatments implemented by the occupational therapists. The adaptive equipment can be also recommended for the child such as assistive walkers, electric wheelchairs, seating systems etc.; Speech and language therapy: The child's ability to speak clearly or to communicate using sign language can be provided with the speech pathologists treatment. If the child has difficulties in communication, it can learn to use communication device, such as augmentative and alternative communication devices, or computer. Speech therapists can also help with eating and swallowing difficulties; Recreational therapy: Some children benefit from regular or adjustable recreational or competitive sports activities, such as therapeutic horseback riding or skiing. This type of therapy can help improve the motor skills, speech and emotional well-being of a child with cerebral palsy (Mayyo, 2019).

\section{Methodology of research}

The aim of the study is to determine the effect of the dog presence during the treatment of children with motor disabilities, i.e., to see if the inclusion of dogs in the therapy of children with various types of motor disabilities will give better results. The research was conducted through case study over a period of three months (from October to December, 2020) with specific cases, consisting of six students with motor disabilities, previously assessed, evaluated and proportionally distributed in the group. This 
group of children with motor disabilities underwent dog therapy, during their classical special education and rehabilitation treatment. Before the start of the treatment, a control assessment of the motor abilities and the behavior during the daily activities of the children was made and based on the results, therapeutic programs were prepared, i.e., work plans with precisely defined goals, methodological procedures and resources. The same assessments were performed on half of the treatment (after 1.5 months) and at the end of the treatment. Checklists and transcripts of video and image data were used to collect data, which we realized through the ATLAS program (a program for qualitative analysis of textual, graphic, audio and video data). First, the effects of the exercises with and without the use of a dog were analyzed, and then a comparison with another similar research was made. We compared the changes in the results with the Difference-in-differences (DID) technique, while the assessments were made using the Adaptive Behavior Assessment System (ABAS) (Harrison and Oakland, 2000-2003). Scale scores are represented by a specific range in a quantitative scale such as: extremely low, marginal, border line, average, above average, superior, very superior.

The research was conducted at Special Center for Dog therapy in Skopje, the sample consisted of 6 children (4 female and 2 male) with motor disabilities, aged between 7 and 9 years. A.E. is 8 years old, female with cerebral palsy, E.S. is 9 years old, female with hemiparesis, A.S is 8 years old, female with diagnosis: orthopedic impairment, E.M is 7 years old, female with severe degree of orthopedic impairment, S.B is 8 years old, male with disharmonious development and D.M is 9 years old, male with disharmonious development, too.

\section{Results}

The initial assessments in the respondents determined results in line with the type and degree of disability, where the children with motor impairment achieved the lowest results in the field of motor skills. In the initial assessment the student A.E. sometimes maintains balance while standing to dress, but is unable to dress on her own. Sometimes she can wash and dry her hands. She is not able to transfer objects without dropping them 
and sometimes she knows how to cross the playground avoiding collisions with objects or persons. She is unable to catch a ball with both hands, she is not able to fasten buttons when needed, cannot use scissors for cutting paper, and has no adequate value for herself. She is unable to write letters on her own using a pencil. E.S is able to maintain balance when needed, but she is not able to dress on her own. She can wash and dry her hands independently. Sometimes she transfers objects without dropping them, catches a ball with both hands and she can throw a ball while moving. She is not able to manipulate small objects and use paper scissors. Moves the body in music rhythm, jumps on both feet and crosses the midline when asked. The student A. S maintains balance while standing to dress and always dresses independently. She transfers objects without dropping them and she is able to catch and pass the ball with both hands. She participates in team play using throwing and catching skills, chasing games, etc. She can hold small objects and use paper scissors. She always crosses the center line; she is able to write letters using a pencil and jumps on both feet when asked to do so. The student E.M dresses independently and maintains balance while standing to dress. She can catch a ball with both hands, she can throw the ball to another child while moving and she participates in team play using throwing and catching skills. She is able to fasten buttons, manipulate small objects and use paper scissors when necessary. Sometimes she moves her body in music rhythm, and always jumps on both feet. She can write letters using a pencil. with music rhythm. Sometimes he writes letters while using pencil.

Table 1. Results of the first motor assessment

\begin{tabular}{llllll}
\hline Examinee & $\begin{array}{l}\text { Sum } \\
\text { score }\end{array}$ & $\begin{array}{l}\text { Percentile } \\
\text { score }\end{array}$ & $\begin{array}{l}\text { Result of the gen- } \\
\text { eral adaptive } \\
\text { composite (GAC) }\end{array}$ & $\begin{array}{l}\text { Confi- } \\
\text { dence in- } \\
\text { terval }\end{array}$ & $\begin{array}{l}\text { Qualitative } \\
\text { range }\end{array}$ \\
\hline A.E & 14 & 0.5 & 61 & $<70$ & extremely low \\
E.S & 17 & 2 & 69 & $<70$ & extremely low \\
A.S & 63 & $>90$ & $111-131$ & $71-79$ & border line \\
E.M & 62 & $>90$ & $119-131$ & $120-129$ & superior \\
S.B & 51 & $>90$ & $111-131$ & $110-119$ & superior \\
D.M & 47 & 82 & 105 & $90-109$ & average \\
\hline
\end{tabular}

The student S.B is able to maintain balance while standing to dress independently. He washes and dries his hands and can move objects freely 
without dropping them. He can throw a ball to another child while he is moving and he can hit a moving ball with his feet. He is able to fasten buttons and manipulate small objects. He can move his body in with the music rhythm. He can jump on one or both legs. The student D.M maintains balance while standing to dress and always dresses independently. Sometimes he washes and dries his hands, and sometimes he knows how to move objects without dropping them. He never participates in a team game using throwing and catching skills. He manipulates small objects and knows how to fasten buttons. Unable to move body

In the group of examinees of children with motor disabilities, we found that the results for the motor abilities were at the extremely low level, some of the children showed improvement in certain segments of the motor skills, which were on a border line, and the children showed perseverance and tried to complete the tasks and activities to the end.

Table 2. Results of the second motor assessment

\begin{tabular}{llllll}
\hline Examinee & $\begin{array}{l}\text { Sum } \\
\text { score }\end{array}$ & $\begin{array}{l}\text { Percentile } \\
\text { score }\end{array}$ & $\begin{array}{l}\text { Result of the } \\
\text { general adaptive } \\
\text { composite (GAC) }\end{array}$ & $\begin{array}{l}\text { Confidence } \\
\text { interval }\end{array}$ & $\begin{array}{l}\text { Qualitative } \\
\text { range }\end{array}$ \\
\hline A.E & 14 & 0.5 & 61 & $<70$ & extremely low \\
E.S & 33 & 25 & 90 & $90-109$ & average \\
A.S & 63 & $>90$ & $111-131$ & $71-79$ & border line \\
E.M & 62 & $>97$ & $119-131$ & $120-129$ & superior \\
S.B & 52 & $>90$ & $111-131$ & $110-119$ & border line \\
D.M & 48 & $>90$ & $108-131$ & $90-109$ & average \\
\hline
\end{tabular}

After one and a half month of performing exercises with the implementation of dog therapy, the second assessment of the student's abilities was made, in order to see to what extent, the skills moved or not in certain domains, especially in the field of motor skills. The performance of the motor skills, and the result of the practical composition of the student E.S with percentile score 25 has increased in the normal range. The student $\mathrm{E}$. $S$ started maintaining balance while standing to get dressed when needed, and sometimes dresses independently. She is still unable to move objects without dropping them, but she started catching a ball with both hands. She is not able to hit a moving ball and to throw a ball to another child while moving. Sometimes she was able to manipulate with small objects. Also, she was able to jump on both feet or on one leg. At this point we 
could conclude that the animal assisted therapy motivates children to actively participate in the therapy, increase their will and desire to work, and the improvement of the motor performances requires long-term and dedicated work to obtain measurable goals.

Table 3. Results of the third motor assessment

\begin{tabular}{llllll}
\hline Examinee & $\begin{array}{l}\text { Sum } \\
\text { score }\end{array}$ & $\begin{array}{l}\text { Percentile } \\
\text { score }\end{array}$ & $\begin{array}{l}\text { Result of the } \\
\text { general adaptive } \\
\text { composite (GAC) }\end{array}$ & $\begin{array}{l}\text { Confidence } \\
\text { interval }\end{array}$ & Qualitative range \\
\hline A.E & 23 & 9 & 80 & $80-89$ & border line \\
E.S & 45 & 75 & 110 & $110-119$ & superior \\
A.S & 63 & $>90$ & $111-131$ & $71-79$ & border line \\
E.M & 62 & $>97$ & $119-131$ & $120-129$ & superior \\
S.B & 55 & $>90$ & $111-131$ & $110-119$ & border line \\
D.M & 50 & $>90$ & $108-131$ & $90-109$ & average \\
\hline
\end{tabular}

The exercises with implementation of a dog therapy continued for three months, and at the end of the third month the third and last assessment was made to see the differences. The performance of the motor skills, and the result of the practical composition of the student A.E from the tertiary and the last assessment of 23 (9 percentile score) went to border line. The student A.E was sometimes able to maintain balance while standing to dress, but never dressed on her own. She could wash and dry her hands independently. She was not able to catch a ball with both hands and also, she wasn't able to fasten buttons. She also had difficulties while using scissors for cutting paper. She was unable to write letters on her own while using a pencil. The performance of the motor skills, and the result of the practical composition of the student E.S from the third assessment showed sum score of 45 (75 percentile score) and increased above the average range. The student E.S was sometimes able to maintain balance while standing to get dressed and always dressed independently. She was able to transfer objects without dropping them, and she could catch a ball with both hands. She was able to hit a moving ball and throw the ball to another child while she was moving. She was still not able to fasten buttons on her own, but sometimes she was able to manipulate with small objects. Also, she was able to jump on both feet or on one leg. She was also able to write letters using a pencil. 


\section{Conclusion and Discussion}

Analyzing the respondents with motor difficulties results, we concluded that the inclusion of a dog in the rehabilitation process did not bring major visible changes in the development of motor skills, but the children persistently tried to complete the tasks and activities to the end. Dog therapy motivates children to participate in therapy (exercises). They have showed great willingness and desire to work and exercise with a dog. These results of our research, to some extent, show an overlap with the research results of Tepfer, Ross, MacDonald, Ruell, Ruaux, and Baltzer, (2017) according to which dog therapy plays an important role in quality of life, physical activity, and motor skills. Dog therapy has a positive effect and gives results in the treatment of children with motor problems.

The summary of the results of our research in relation to the motor disability and children's functionality, we can underline the following conclusions: Dog therapy provides a quick connection between children, strengthens the social bond and improves interaction between children; Dog therapy can be an effective and quick intervention in helping children physically, especially in fine motor skills; The presence of the dog has the potential to stimulate social-verbal communication in daily activities; Therapies and activities with the help of dogs can be a method of support for the rehabilitation of children with motor disorders and difficulties in the field of socialization.

Many animal therapy studies point to a wide range of health benefits for people involved in treatment, but many of the researches are characterized by small interventions in various areas, resulting in criticism of poor study design or inconsistent methodology. Such criticisms contradict the strong claim among many that animal interaction has a strong and innate value to those involved. And our study is characterized by a small sample and a short period of intervention. To fully integrate animal therapy into practice as an accepted therapeutic modality, more convincing studies are needed to confirm clinical values, along with understanding the basic mechanism of human reaction to the presence of animals.

Concluding these we believe that as proposed measures we need to implement the assistance of a therapeutic dog during the treatments of children with motor disabilities; Organized realization of activities with 
therapeutic dog in regular and special schools; Training of medical and school staff, and parents for the elementary behaviors of a therapeutic dog; Creating a network of cooperation of dog centers, social centers and primary schools, in order to perform advisory work with parents for properly implementation of dog therapy with their children during the daily activities.

\section{References}

Alliance of Therapy Dogs. (2018, July 11) A History of Animal-Assisted Therapy, retrieved January 10, 2021, from https://www.therapydogs.com/animal-therapy/.

American Veterinary Medical Association. (2019) Animal-assisted interventions: Definitions, retrieved February 12, 2021, from https://www.avma.org/resourcestools/avma-policies/animal-assisted-interventions-definitions.

Ajdinski, G., Kitkanj, Z. and Ajdinski, Lj. (2007). Osnovi na defektologijata. Basis of Special Education and Rehabilitation. Kumanovo, Macedonia: Makedonska Riznica.

Arifi, V. and Rashikj-Canevska O (2020). Efektot od terapijata so kucinja vrz decata so poprecenost. The Effect od the dog therapy on the children with disabilities. Master thesis. Institute of Special Education and Rehabilitation. Skopje, Macedonia.

Becic, S. (2019). Top 10 benefits of therapy and service dogs. Health fitness revolution, retrieved January 15, 2021, from https://www.healthfitnessrevolution.com/top-10benefits-therapy-service-dogs/.

Baun, M.M. and McCabe, B.W. (2000) The role animals play in enhancing quality of life for the elderly. London, UK: Academic press.

Clonowski, J. (2015) Therapy dogs - The Different types and their benefits. Feinberg consulting, Retrieved November 1, 2019, from https://feinbergconsulting.com/therapydogs-the-different-types-and-their-benefits/.

Cockerham, W. C. (2016). Sociology of mental disorder. New York, USA: Routledge.

Çolak, E., Özkan, B., Genç, S. and Polat, B. (2021). Ultrasonographic determination of thyroid volume in infants and children from Aegean region of Turkey and comparison with national and international references. Journal of Pediatric Endocrinology and Metabolism, 34(4), 457-464. https://doi.org/10.1515/jpem2020-0514.

Elmaci, D. T. and Cevizci, S. (2015) Dog-assisted therapies and activities in rehabilitation of children with cerebral palsy and physical and mental disabilities. NCBI, retrieved March 6, 2021, from https://www.ncbi.nlm.nih.gov/pmclarticles/PMC4454953/\#B12-ijerph-12-05046. 
Fine, A. (2000) Animal assisted therapy - Theoretical foundations and Guidelines for practices. London, UK: Academic press.

Harrison, P. L., and Oakland, T. (2000). Adaptive behavior assessment system. San Antonio, TX: Psychological Corporation.

Howell-Forbes, E. and Marxen, K. (2014) Animal-assisted therapy: A dog's influence on occupational therapy outcomes of a child with cerebral palsy (Master's Thesis). University of Puget Sound, Takoma, USA. Retrieved from: https://soundideas.pugetsound.edu/ms_occ_therapy/97/.

Henderson, J. M. (2012). Motor impairment. International Neuromodulation Society, retrieved January 15, 2021, from https://www.neuromodulation.com/motorimpairment.

Krigger, K. W. (2006). Cerebral palsy: an overview. American family physician, 73(1), 91100. https://www.aafp.org/afp/2006/0101/afp20060101p91.pdf.

Kruger, K. A. and Serpell, J. A. (2010). Animal-assisted interventions in mental health; Definitions and theoretical foundations: Handbook on animal-assisted therapy. https://doi.org/10.1016/B978-0-12-381453-1.10003-0.

Kruger, K. A. and Serpell, J. A. (2006) Animal assisted interventions in mental health. In Handbook on Animal-Assisted Therapy: Theoretical Foundations. London, UK: Academic Press.

La France, C., Garcia, L., and Labreche, J. (2007) The effect of a therapy dog on the communication skills of an adult with aphasia. Retrieved from: https:/www.ncbi.nlm.nih.gov/pubmed/16950329/.

Levinson, B. and Mallon, G. (1997) Pet-oriented child psychotherapy. Springfield, IL: Charles C. Thomas.

Lundqvist, M., Carlsson, P., Sjödahl, R., Theodorsson, E., and Levin, L. Å. (2017). Patient benefit of dog-assisted interventions in health care: A systematic review. BMC complementary and alternative medicine, 17(1), 1-12. https://doi.org/10.1186/s12906-017-1844-7.

Marcoux, H. (2019). 10 Types of Service Dogs and What They Do. Dogster, retrieved February 15, 2021, from https://www.dogster.com/lifestyle/10-types-of-service-dogs-and-what-they-do.

Mayyo, C. S. (2019). Cerebral palsy - Diagnosis and tratment. Mayo Clinic, retrieved March 17, 2021, from https://www.mayoclinic.org/diseasesconditions/cerebral-palsy/symptoms-causes/syc-20353999.

PAWS. (2005). Benefits of pet therapy. PAWS for people, retrieved December 23, 2020, from https://www.pawsforpeople.org/wpcontent/uploads/2011/07/benefits-of-pet-therapy.pdf. 
Palisano, R., Rosenbaum, P., Barlett, D., and Livingsto, M. (2007). Gross Motor Function Classification System . CanChild Centre for Childhood Disability Research, retrieved March 17, 2021 from https://www.canchild.ca/system/tenon/assets/attachments/000/000/058/orig inal/GMFCSER English.pdf.

Pavone, V., and Testa, G. (2015). Classification of cerebral Palsy. In F. Canavese and J.Deslandes (Eds.), Orthopedic Management of Children with Cerebral Palsy. A Comprehensive Approach (p.75-98). New York, USA: Nova.

Pillow-Price, K., Yonts, N., and Stinson, L. (2014) Sit, Stay, Read: Improving Literacy Skills Using Dogs. Dimensions of Early Childhood, 42 (1), 5-9. Retrieved from https://files.eric.ed.gov/fulltext/EJ1044105.pdf.

Rosenthal, H. (2020). Human Services Dictionary: Master Reference for the NCE, CPCE, and the HS-BCPE Exams. New York, USA: Routledge.

Sanger, T. D. (2015). Movement disorders in cerebral palsy. Journal of Pediatric Neurology, 13(04), 198-207. http://dx.doi.org/10.1055/s-0035-1558866.

Staff, E. (2018). Understanding the Benefits of Animal-Assisted Therapies. American Addiction Centers, retrieved January 15, 2021, from https://americanaddictioncenters.org/therapy-treatment/animal-assisted.

Shroff, G., Gupta, A., and Barthakur, J. K. (2014). Therapeutic potential of human embryonic stem cell transplantation in patients with cerebral palsy. Journal of Translational Medicine, 12(1), 1-9. https://doi.org/10.1186/s12967-014-0318-7.

Tingle, M., and Nelsin, N. (2005). Motor impaired child. England, UK: Taylor and Francis e-Library.

Tepfer, A., Ross, S., MacDonald, M., Udell, M. A., Ruaux, C., and Baltzer, W. (2017). Family dog-assisted adapted physical activity: A case study. Animals, 7(5), 35. https://doi.org/10.3390/ani7050035.

\section{Citation Information}

Rashikj Caneska, O. and Ramo Akgün, N. (2021). Dogs therapy for children with motor disabilities. OPUS- International Journal of Society Research, 18(41), 3099-3116. DOI: 10.26466/opus.937387. 